Chapter 14

\title{
The Mixed Balance of History
}

The legacy of Christianity is not altogether glorious. There are things to be proud of; there are also things to be ashamed of. Everyone involved in communicating the Gospel in one part of Europe or another will have the same experience: so many people want to stay away from the message because of the negative picture of Christianity in general, and church institutions in particular. The negative record of Christians is always a major hindrance for evangelism, but nowhere is the criticism levelled against Christianity as widespread and as strong as in Europe.

The negative image of Christianity is largely based on its past record. The problem is that this characterization contains a considerable amount of truth. Europe is marked by the influence of Christianity, but not always in a positive way. Churches have often played a dubious role, to say the least. One thinks, for example, of the violent persecution of so-called heretics, dissenters and non-conformists by the combined forces of church and state authorities.

Today Europeans have lost much of the feeling of superiority they had in the past. Instead, they have become critical of their own history. In this context, people are very much aware of what church leaders and lay Christians have done wrong in the past. Sadly, blame is often levelled against European Christianity as a whole. Sometimes Christianity is discredited as far as its place in the public sphere is concerned. Many secularised people hold to the opinion that it is alright for people to practice their faith in the private sphere, but don't want the church to try and dominate the public sphere, or influence the political debate so as to impose its views. Enough of that has happened in the past.

Generalisations always fall short of reality. The categorical criticisms levelled against 'the church' are no exception. When we look at history, we have to admit that much harm has been done in the name of Christianity, but also recognize that Christians were often the first to speak out in protest against that. This should also be taken into account. So let us set the record straight.

\subsection{Setting the Record Straight}

The late archbishop of Paris, Cardinal Jean-Marie Lustiger (a Jesus believing Jew), has repeatedly challenged both timid Christians and staunch critics of religious involvement in the public place to set the historical record straight. 'Part of the 
challenge we face today is to recognize that Europe (and indeed the entire West) is suffering from a false story about itself, and about the relationship of Biblical religion to its formation and its history. ${ }^{167}$

In his frequent appeal to critically engage modern culture so as to remind it of its indebtedness to Christianity, the American Roman Catholic author George Weigel asserted that 'the Church needs to be vindicated from the "black legends" that circulate around its history, such as the Crusades, Galileo's trial and the Inquisition.' ${ }^{168}$

However, there is no room for triumphalism. We should understand these statements in the context of the debate with those who defend a secular humanist approach to the development of modern society. Certainly, it is a good thing to correct the negative view of the role of the church. But when we set the record straight, we should not overstate the case by emphasising only the positive side of it while underestimating or even ignoring the notorious role it has often played. It is a matter of intellectual honesty to recognize sins, to rectify false teaching, and to ask forgiveness for the wrong that has been done. Cardinal Walter Kasper strikes the necessary honest tone, when he says:

Besides the magnificence of Europe, there is also the misery and the shameful history of Europe. Europe has often betrayed its high ideals: in the crusades, in the religious wars, in the colonising of other peoples, in two world wars and at least in the Shoa, the destruction of European Jewry. Theses dark sides of our history have contributed to an uncertainty of our identity. ${ }^{169}$

Wim Rietkerk concurs. He cautions that when we only put forward the positive outcomes of Christianity, this can easily smack of Eurocentrism. We should beware of doing that because Europe has hardly been a good example.

In fact, when taking stock today of so many centuries of European history, we should all be very regretful. Right from the beginning there was a deep sinfulness and violence in European culture, in which church and state conspired together. The same Charlemagne who created a form of European unity, killed 4500 Saxons in one day because they did not want to be baptised and enter the Christian world.

167 Quoted by the American author Georg Weigel in his address during the Lustiger Symposium at the Collège des Bernardins in Paris, 11 February 2010.

168 Idem.

169 Walter Kasper, public address at the occasion of the 70th anniversary of Erwin Teufel, former Prime Minister of Baden-Württemberg, in Tübingen, 12 October 2009. 
Later came the crusades, then the religious wars, then slavery, then colonialism, and finally, in the twentieth century, Europe burst into flames during two world wars. Hardly a history to be proud of at all! ${ }^{170}$

However, we should not go to the other extreme and become so guilt-laden that we no longer dare to speak positively of the blessings of the Christian heritage. Moreover, when we admit the complicity of the church in the shameful events of the past, we should also recognize the Christian counter movements and individual voices that spoke out against it, in the name of faith. We mention a few examples.

\subsection{Complicity with Injustice, Protests and Alternatives}

European Christianity has been blamed for suppressing freedom, condoning warfare, fuelling feelings of nationalism and racism, supporting slavery, collaborating with colonialism, and inventing capitalism, to name but the most frequent accusations. Going over this list and looking back to what happened, we notice that Christianity was part of the problem and at the same time a source of protest and reform.

\section{The Church became her own critic}

The cross was the supporting beam of the power structures of states in alliance with the church, but at the same time it was the thorn in the flesh of those who used their power for their own interests only. It is the French historian, Jacques Dalarun, who remarks on this in his study of medieval Christianity and the question of governance. As a specialist in medieval history he cannot but acknowledge that this period was marked by the absolute ideological domination of Christianity.

But the Church also transmitted the words of Christ that was very critical of the abuse of power. This critical attitude towards power structures, which is intrinsic to the Gospel, caused people to have fundamental doubts about the established order of their day, and indeed of all sorts of power politics.' As a result, the church became her own critic!

We should not forget that the Church in the past has often been subservient to the established powers, but time and time again there was a return to the Gospel which put Christians in opposition to a society where people were treated

170 Wim Rietkerk, 'God's Experiment'. See bibliography for details [16 May 2010]. 
unequally, on the basis of birth or physical power. On the one hand, there was the world of warriors and princes where people were heavily dominated. On the other hand, there were the monasteries, where the abbot was the servant of all servants. One could say that these were two opposing models. In reality, they created a tension, a permanent dialectic. ${ }^{171}$

Dalarun shows that the monasteries developed a form of democracy, based on the model 'to govern is to serve.' He corrects the generally accepted idea that the history of modern democracy started with the Enlightenment and the French Revolution, which adopted the democratic model of Athens and the Greek philosophers in Antiquity. 'We cannot just jump from the Enlightenment to Antiquity, and say that the Church in the meantime has contributed next to nothing to modern democracy,' he argues. 'Of course, the medieval Church did not invent it, but there have been real attempts to develop democratic forms of governance on a limited scale. ${ }^{172}$

All over the Christian world there have been repeated attempts to confront kings and rulers with the Biblical demands of justice, equity and mercy. The voice of the Bible offered checks and balances to political power. Several parliaments came in existence because the leading class of citizens presented the princes with their demands.

To this we should add the forms of governance developed by followers of the Protestant Reformers in the Netherlands during the seventeenth century. In their model, the prince did not have absolute power, he could govern in collaboration with the representatives of property-owning citizens. This model influenced Enlightenment thinkers as they developed their ideas of representative democracy.

What we are saying, then, is that the church has played more than one role. While we can blame Christians for being compliant with power politics, intolerance and the like, we should also give credit to Christians who have been inspired by the Gospel to take alternative positions.

In the following, we shall mention and shortly discuss five accusations levelled against European Christianity.

Intolerance and freedom

First on the list is the issue of intolerance and freedom. Mariano Delgado has taken up the challenge and prepared a defence. He explains that Europe was for many centuries a 'Christian project.' The church and the state worked together

171 Jacques Dalarun, interview in La Croix, 28 September 2012, in which he comments on his book Gouverner c'est servir.

172 Idem. 
to develop a corpus christianum. But the seeds of the Gospel were gradually yielding other fruits that were not to the liking of the institutional church: fruits of individual freedom, equality, and brotherhood based on respect for the innate value of each individual human being. Enlightenment philosophers reaped them, and the French Revolution made them the foundational marks of a new social order, in which there was no place for a dominant and privileged church.

But why was this Revolution so vehemently anticlerical? Why did it choose the slogan Ni Dieu, ni maitre ('neither God nor master')? Why did its militants ransack convents, turn monasteries into military barracks and church buildings into stables? Why all of that, only in order to implement ideas that were essentially rooted in the Biblical message that every human being is created in the image of God?

On the one hand, the French Revolution would not have been possible without the experience of Europe as a Christian project. On the other hand, we must acknowledge that a secular Humanism also developed that did not need to refer explicitly to Christianity as its foundation, a Humanism that considered Christianity to be its negative flipside, precisely in the area of religious freedom. Delgado explains:

This human right of freedom, which is so dear to us nowadays and which is an indispensable element of the Christian view of man, also in the eyes of the Church, had to be fought for in a fierce battle with the intertwining forces of state and Christianity, in the French Revolution. Only through this battle did this alliance of state and church, in which Christianity was considered to be the public religion of society, collapse in the western world. This was mainly the consequence of the religious wars and the experience that religion opposed people instead of being the basis of peaceful living together in one society. ${ }^{173}$

We should not forget that the development of the religious neutrality of the state and of a secular pluralistic society came about in this historical situation of the western world. In those days the religious parties were unable to relate the official and obligatory character of this religion to every individual person's right to freedom of belief and conscience. In order to realise the personal right of freedom, the state put an end to its amalgamation with the dominant religion. When Mariano Delgado describes this conflict, he thinks mainly of Roman Catholic countries. There, the opposition of the secular state to the institutional church has been fierce, as he himself points out:

173 Mariano Delgado, 'Europa als christliches Projekt,' in: Urs Altermatt, Europa: ein christliches Projekt, p. 52. Our translation from German. 
With her faith in the moral equality and the freedom of all human beings, the church had laid the foundation of freedom but she did not understand the logical consequence of this faith, namely a society based on the equality of all citizens and the autonomy of secular political authorities. Those who fought for personal freedom saw the church in those days as a barrier, or even as an enemy, so they became anticlerical. The idea of equality and freedom that had been fostered by the church turned against the institutional church. ${ }^{174}$

In countries where Protestantism was the dominant form of Christianity, this conflict was not so intense. Nevertheless, the institutional Protestant churches in their alliance with monarchs and emperors have also been a hindrance to the development of individual freedom.

On the other hand, we should not forget that Christians were the first to strive for freedom. Think of the persecuted Protestants in France and the nonconformists in England who appealed to the individual conscience of the believer over and against doctrinal and political tyranny. They formulated the principle of freedom of conscience and the freedom to practice one's religion, according to one's conviction. This principle became a foundational element for Enlightenment philosophers and the American Revolution. It was included in the 'Human and Citizens Rights,' promulgated after the French Revolution, and integrated into the constitutions of all modern states.

\section{Colonialism}

Another black page of our history is colonialism. European Christianity is often put wholly on the side of colonialism, but notice that it not for religious motives but for reasons of commerce, protection of trade routes, development of plantations, exploitation of natural resources and extending political power that several European nations set up colonial empires. It was a matter of imperialism, not of Christian mission. It was for gold and silver that the Spanish explored the Americas and subdued its indigenous peoples. It was for lucrative commerce that the Portuguese set up colonies along the newly explored trade routes.

Once the process of colonisation had begun, the pope came in with the demand that the Roman Church be implanted in the colonies. So Franciscan, Dominican and Jesuit envoys went out to Christianize the indigenous people. It is at this point that the imbrications of colonialism and mission began, and the church has been blamed for this ever since. The accusation is that Christianity simply supported colonialism and condoned its excesses. A closer look reveals that the truth is a bit more complicated and less negative than that.

174 Idem. 
The missionaries set up mission stations with farms, schools, medical hospices, churches (including choirs, church bells and church organs!). Many major cities in Latin America and in the USA have grown out of these missions. San Diego and San Francisco are well known examples. Historian Dana Roberts explains that the reasons for building them where twofold. 'The overriding concern was pragmatic for missionaries: the need to grow food for themselves and their converts. Successful food production and the provision of water resources were not only necessary for survival. At the same time, they were, in the minds of both missionaries and converts, a visible symbol of the superiority of Christianity over traditional ways of life. ${ }^{175}$

Christian mission developed under the umbrella of colonial rule that offered missionaries protection and land. Following the feudal European pattern, the conquerors gave land rights to colonists and church leaders, so that they became lords over the indigenous people.

However, while they profited from the colonial system and seriously limited the freedom of local people, missionaries were also highly critical of its excesses. They defended land of indigenous people against pressure from colonists to apprehend it. They openly challenged the idea, defended by European rulers and theologians, that Indigenous people were an inferior race, or perhaps sub-human and that they could therefore be exploited and relegated to an inferior status. These are men and women created in the image of God, they protested, just like Europeans. One of them, Bartholomeas de Dias, even went to a dispute organised by the king of Spain to defend this point of view.

Later on, Protestant nations developed their colonial empires. They also acted for economic gain and political power, but again missionaries followed the merchants and the soldiers. They also set up mission stations, with schools and churches and farms, for the same reasons that the Catholics had done this earlier, but contrary to the procedure in Catholic colonies mentioned above, they had to buy their land.

Dana Roberts explains that the acquisition of mission stations 'required complex negotiations among missionaries, chiefs or local rulers, and the colonial powers. Since missionaries brought with them Western education and medical care, and acted as mediators with the colonial officials, local leaders competed with each other to have their own resident missionary.' She goes on to cite two telling examples of the way in which the Christian mission often acted in favour of the indigenous population, against the interests of colonists and governors:

175 Dana Roberts, Christian Mission, p. 107. 
In 1833, a Sotho leader named Moshoeshoe invited two missionaries from the Paris Evangelical Missionary Society to become his counsellors and to move his people toward Christianity and Western education. With the assistance of the missionaries, Moshoeshoe was able to consolidate the boundaries of what became Lesotho and prevent its takeover by white colonists. Similar missionary assistance prevented Botswana from being incorporated into white-dominated South Africa. ${ }^{176}$

Regularly, colonial rulers seized land and allocated it to the major church denomination of their own country, expecting the missionaries to civilize the so-called 'natives.' Christian mission was seen as a useful way to do that, all the more so since the missionaries themselves were motivated to introduce European education, medical care, manners and organisation as part of the new, Christian way of life.

We should add that Enlightenment thinkers accepted colonialism, if only for the time being, because they saw it as a means to civilize the dominated peoples. This was the good end that justified questionable means. Only very few 'enlightened' minds raised questions with respect to the objective as. Generally speaking, European nations found that adopting their civilisation was a form of progress. . ${ }^{177}$

However, missionaries were also the first to recognize the value of indigenous cultures, to defend the rights of indigenous peoples, and to oppose the greedy exploitation of their lands by European companies.

\section{Slavery and abolitionist movements}

Closely connected to colonialism is another dark side of European history; slavery. Again, blame is often levelled against Christianity for having condoned and even supported this tragedy that went on for more than three centuries and which has left indelible an mark even today.

Slavery as such is not an invention of the 'Christian' Europeans. Already in Biblical times, slavery existed to different degrees, from servitude to bonded labour and cruel exploitation. In ancient Israel there were also slaves, but the way in which they should be treated according to the Torah was exceptionally humane at that time. After seven years, any bonded servant should be given the opportunity to become a free man!

The Greeks and the Romans had slaves - and looked down on them. The economy of the Roman Empire was even built on this system. The Arabs traded slaves from East Africa to the north.

176 Dana Roberts, op cit., p. 108-109.

177 See chapter 3.3 'Europe as Civilisation'. 
Even so, these parallels in history do not take away the gravity of the facts: European merchants captured more than thirty million Africans, shipped them to the other side of the Atlantic, and sold the survivors as slaves to European planters in the colonies. Having emptied their ships of their human 'load,' they filled them with sugar and other products, which they sold in the markets of western Europe, as well as gold and silver. This triangular trade was extremely lucrative; it made merchants wealthy and secured the prosperity of cities like Lisbon, Cadiz, Nantes, Amsterdam and London.

To the slave trade we should add the system of slavery. 'Christian' masters treated their African slaves as less than human. Given the treatment these people had to endure, it is all the more incredible that they accepted the Gospel presented to them by evangelists who were more often than not financially supported by the churches of the plantation owners.

It cannot be denied that theologians have defended slavery. Churches have not disciplined members who clearly violated Biblical commandments with regards to their slaves. One could be a slave trader and a church member without any problem. The system was condoned by Roman Catholic and Protestant clergy alike.

So is Christianity to be blamed for having sanctioned this horrible and repulsive treatment of millions of Africans? Yes and no. While many church leaders collaborated, others resisted. While some preachers of the Word appealed to the Old Testament to justify the slave trade and the slave system, others appealed to the same Bible to speak out in protest. It was only a matter of time before the seeds of human dignity and 'love your neighbour as thyself' began to yield the fruit of a movement calling for the abolition of the slave trade and slavery. The first abolitionists were evangelists in the eighteenth century. Some Enlightenment philosophers were won for the same cause, though others did not seem to bother. It is striking that the founding fathers of the US, who were very much influenced by Enlightenment philosophy, based their constitution on the principle that 'all men are born equal and merit therefore freedom and happiness,' but did not extend these rights to the black population that suffered on the plantations.

The French Revolution revealed similar contradictions. While the deputies in the National Assembly abolished the cruel slave trade, it maintained the system of slavery.

Many leaders of the so-called abolitionist movements were Evangelical Christians: Gospel preachers, pastors, politicians, writers, including converted slave traders such as John Newton. Most famous among them is perhaps English member of parliament, William Wilberforce. It was mainly due to his influence that the British government abolished the slave trade in 1807.

But slavery continued. Abolitionists had to fight a long battle with politicians concerned with economic interests and fellow Christians condoning the system to have it abrogated. But their movement could not be stopped. In 
the course of the nineteenth century, abolitionists succeeded in influencing public opinion and convincing reticent politicians to put an end to this scandal in the Christian world. Great Britain was the first to do so. In 1833 it adopted the Slavery Abolition Act that outlawed slavery in the entire British Empire. A copy was brought to William Wilberforce on his deathbed; it was read out to him only days before he passed away. The struggle in the US was much more difficult. The southern states didn't want to give it up. It took a bloody four-year civil war before black Americans obtained freedom and civil rights (1858). Their segregation continued, only to be abolished in the 1960 s under the pressure of the civil rights movement, lead by yet another Gospel preacher, Martin Luther King Jr.

\section{Capitalism and Christian social movements}

We mention a third dark side, although not everybody would agree to what extent this was indeed a negative part of European history: capitalism and the Industrial Revolution. The latter was based on (1) the application of science and technology to production processes and new products; (2) an effective division of labour; (3) the distinction between capital and means of production on the one hand and labour on the other hand.

From the outset, industrialisation and capitalism went hand in hand. As profits for investors far outweighed the wages for labourers, the gulf between rich and poor widened. But investors could also lose all their capital overnight, a risk that is not often appreciated in criticisms of capitalism.

The Industrial Revolution accelerated economic development and made mass consumption possible; it led to the modern consumers' society, first in Europe and the USA, and then in other parts of the world. But the industrialisation also brought exploitation of workers, unhealthy working conditions and deplorable housing conditions, uprooted family life, child labour and other forms of social injustice. It also deepened the rift between rich and poor.

Reactions to these negative effects of capitalism combined with industrialisation were diverse. The most powerful ones were socialism and communism, based on the theories of Karl Marx and Friedrich Engels. These movements did not reject industrialisation as such but the capitalist economic system. Towards the turn of the twentieth century, there was a divide between revolutionary communism on the one hand, and evolutionary socialism on the other hand. The latter accepted multiparty democracy and strove to reach its goal through peaceful means within the present system. This has in due time become social democracy.

It should be noted that communism and social democracy are European phenomena though they have spread to other parts of the world, where they have taken on a local colour. We have Chinese and Cuban style communism, African and Latin American versions of socialism, but this does not alter the origin of the basic ideas. 
What about the church? It cannot be denied that church leaders and Christian entrepreneurs have supported both capitalism and industrialisation. Moreover, many Christians took a position against socialism and communism because they were put off by the anti-religious rhetoric of these movements.

However, there is another side to the coin. In the course of nineteenth century, Protestant and Roman Catholic social movements developed. Social justice was their agenda, the Bible their source of inspiration. They protested against the capitalist exploitation of industrial workers. At the same time they provided an alternative to the communist secularist agenda in which there was no place for religion.

Proponents of this Christian counter-current are the Social Gospel movement in the United States, the Christian Socialists in the UK, the 'Reveil' movement and Abraham Kuyper in the Netherlands, and various Christian politicians and entrepreneurs who worked for social reforms such as Lord Shaftesbury in England and Raiffeissen in Germany. One also thinks of the call of the Roman Catholic Church for social justice (e.g. the famous document Rerum novarum). As for the Ecumenical Movement in the twentieth century, it has always strongly emphasised the need to defend the rights of the poor, and to liberate them from oppressive economic structures.

Granted, these individuals and movements were not welcomed by the whole of the Christian community. They were often suspected of socialist sympathies; a very serious 'sin' in the eyes of their brethren. Free enterprise, free market and individual competition were widely favoured; the economic disparities between rich and poor were often accepted as an inevitable evil in a fallen world order. Then there was the Calvinist idea that material wealth was God's reward for industriousness and prudent management of financial resources.

Here we notice again the dual role of European Christianity. On the one hand, it has fostered capitalism and accepted the conditions of the Industrial Revolution so that it contributed indirectly to its negative effects. On the other hand, it has given birth to movements that were highly critical of this development. Christian politicians have played an active role in implementing laws putting an end to social injustice. Christian organisations have done much to relieve the social and economic distress of working people.

Anti-Semitism and solidarity with Jews

We cannot review the historical record of European Christianity without mentioning Christian anti-Judaism. Certainly, the problem is older than the church. Anti-Semitism was already widespread in the Roman Empire and Persian Empire as the Book of Esther makes clear. But when Christianity became the established religion in the east and west of Europe, it fuelled these age-old antiSemitic sentiments in a dramatic way. Throughout many centuries, the church rejected the Jews as a nation, suppressed their religious practice, accused the Jews of having murdered Christ, and took discriminatory measures by enclosing 
them in ghettos. In so doing, the church fostered popular anti-Semitism, and this in turn has made it possible for the Shoa, this tragedy of all European tragedies, to take place in the most Christianised of all continents.

Did the Shoa happen despite Europe's Christian roots, or as a result of them? Is the church to be blamed? Yes and no. While the church has practiced antiJudaism, some of her members have emphasised that the Jews are still God's chosen people and that they be should be respected as such. While most theologians taught that the promises of the prophets with respect to the future restoration of Israel applied in a spiritual sense to the church, some theologians maintained that they still apply to the Jewish people. While most Christian folk did not care at all about what would become of the Jewish people, some Christians helped Jews return to their homeland, pleaded the cause of Jews who were accused of treason, sheltered Jews who were persecuted, and saved Jews from being killed. Yes there are Christian anti-Semites, but there have also been Christian friends of the Jewish people.

\section{Conclusion}

We conclude that European Christianity has brought great blessing but also done considerable harm. This chapter, as well as the preceding one about Europe's Christian heritage have demonstrated this. Our conclusion is that by and large Christianity has been a blessing for Europe. We say this without ignoring the problematic elements of its past record, the many things that we should be ashamed of as heirs of our Christian forefathers. In the final analysis, the balance sheet shows a positive result indeed!

\subsection{Theological Interpretations of 'Europe'}

From a human point of view we could leave it at that, but as believers we want to consider another aspect as well, i.e. the theological significance of it all. We believe that God intervenes in the affairs of human individuals and families and peoples. Wherever the divinely revealed Word is announced the Holy Spirit works to bring it to fruition. The Spirit continues to work in the people who live according to this message after the example of Christ. And this has an effect on their surroundings, the social structures in which they live.

We believe in common grace illuminating man's notions of good and evil. We believe in divine providence. We believe that God brings about his plans, interacting in a mysterious way with the affairs of men and women on this earth. All this sounds like solid theology to Evangelical ears. But if we affirm this, what does this imply for the case of Europe? This continent has been exposed for a long time and so intensively to the message of the Bible and to the active presence of Christian churches - more than any other part of the world. It seems 
difficult, then, to escape the conclusion that God is somehow involved in the development of European cultures and societies.

Moreover, we should do justice to the work of God through the Christian church in Europe's history, and not attribute all the results of the prolonged influence of the Biblical message to human factors only.

The question is how do we relate the human scene to God's influence. What is our theological interpretation of the phenomenon of 'Europe?' Where is God's hand in all of this? Several theologians have formulated answers to this question, trying to do justice to both the positive and the negative results of European Christianity.

God's experiment?

Believing that God has revealed basic moral values and a notion of his existence to all mankind, in the conscience of every individual, Wim Rietkerk asks the question: how is it possible that European cultures developed in such a specific way, different from those of other peoples? He qualifies Europe as 'God's experiment'178 - an expression borrowed from Anton van Ruler, a Dutch Reformed theologian who wrote, in the decade following the Second World War:

The Holy Spirit converted pagan hearts but at the same time He created out of them a Christianised culture. The sinful pagan existence was not removed but renewed. God's purpose was a visible demonstration of the coming Kingdom as a foretaste of what would happen when Jesus would come back and when all of creation will be renewed. Looking at the history of Europe against the backdrop of the work of the Holy Spirit [in societies and cultures], it was an attempt of God to give a foretaste of the coming Kingdom. ${ }^{179}$

We find this formulation too optimistic. It does not keep the necessary distance between the sinful world of Europe and the Kingdom of God. While developing the idea of Europe as God's experiment, Wim Rietkerk employs the image of gradually moving towards a synthesis. For centuries, Christianity was dominant, while paganism and humanism remained the undercurrent. At the time of the Enlightenment this began to change. By the twentieth century, the undercurrent of a non-Biblical world view has become dominant, and Christianity an undercurrent. 'We could perhaps see this as God's judgment on Europe,' he comments. 'Observing our situation today, our response should first be one of real mourning, of repentance and of prayer.'

178 Wim Rietkerk, op. cit.

179 Quoted by Wim Rietkerk, op. cit. 
Fruits of the fruits of the fruits of the Spirit

Theologian and noted critic of modern western culture Francis Schaeffer asked: how is it possible that many individuals are not Christian but that the norms and values of our society circle around Christian values? His explains that 'the key elements of European civilisation are the fruits of the fruits of the fruits of the Spirit.' It is like a stone thrown in the water, creating ever wider concentric circles. The further away from the first impact of the stone, the vaguer the circle.

It starts with the individual. The fruits of the Spirit in the individual begin in their own lives, and then create institutions and values in a culture, which make it possible also for non-Christians to participate [in the wider effects of Christian presence] and so share in the fruits of the fruits of the fruits of the Spirit. ${ }^{180}$

The flip side of this is the dual attitude of many people today. They recognize the important influence Christianity has had on the past, but they consider it irrelevant for society today. While they applaud the social actions of the church in favour of the poor, they do not find her message of salvation relevant for today's problems. Our society is attached to the fruits of the fruits of the Christian message, on a social and cultural and educational level, but the primary fruit of a restored, reconciled relationship with God is left aside as a private affair of those who believe in Him.

\section{Wheat and tares}

We would propose another interpretation of the phenomenon of Europe. It is like the field in the parable of Jesus where wheat is sown but other seeds as well. Both grow together (Matthew 13). This seems a suitable image. Christianity has sown much good seed and this has produced wheat, yet other religions and philosophies have sown their ideas, values, images of God and man. This has produced all kinds of weeds that hamper the development of the grain. For the time being, until the coming of our Lord, it is impossible to separate the two without doing harm to the good seed. So we have to accept a situation like that of a field with a mixed produce. Sadly, the weeds limit the quality of the crops. On the other hand, the good seed coming up limits the proliferation of the seeds sown by the 'enemy' in the hearts and minds of our fellow Europeans. The presence of the church as light and salt and leaven in society is a restraint, preventing the field from being completely dominated by the weeds.

We need to add that this image is not as simple as it might seem at first glance. The wheat is not wholly on the Christian side, nor are the weeds only

180 Quoted by Wim Rietkerk, op. cit. 
found 'in the world.' Jesus used this image in connection with the Kingdom of God. The Kingdom is not to be equated with visible forms of Christianity. Weed is being sown in the world, but also in the minds of individual believers, in church communities, in Christian institutions. That's why European Christianity has not only brought blessing to society, but also harm.

\section{Cautions}

The parable of the wheat and the tares makes us cautious. It invites us to be honest about ourselves. It also invites us to detect the weeds in our midst. We should discern all spiritual values, worldviews and political promises against which we come up, in the world as well as in our own midst, putting them to the test of God's Word, in order to retain what is good.

Another caution is that we are not in a position to uproot all weeds so as to create an ideal society. When Christianity was the majority religion, Christians often sought to prematurely 'pull the weeds' of other creeds and faiths by legally imposing (their form of) Christianity on everyone else. This has lead to intolerance and persecution. This in turn has alienated many people from a living faith in Jesus Christ.

When Christians were in a minority position, they have often sought to prematurely 'get away from the weeds' by isolating themselves from society and culture, only to discover that weeds were growing up in the midst of their subculture, even in the splendid isolation of monasteries and individual prayer cells! In other words, there is no way of escaping the harsh reality that there is no wheat without weeds.

As for us, we are called to sow the good seed, so that our societies can benefit from its fruit and be nourished by it. The image also stimulates us to make a positive contribution to society. We cannot prevent weeds from growing up, but instead of lamenting the sort of Europe under the influence of materialism, secularism, esoteric thought, nationalism, violent fundamentalism of all sorts, anti-Christian sentiments, counter-Biblical ethics and what have you, we can follow the advice of Paul that only by doing good will we overcome evil. So we want the seed of the Gospel to spread, sprout, grow and yield fruit, in churches as well as in societies at large. 
